原 著

\title{
アルギン酸による印象時の気泡発生及び模型への 影響について
}

\section{1. 印象時の処置と気泡発生の関係について}

\author{
松尾悦 郎*
}

まえがき

アルギン酸印象に際しての気泡の発生ということに は，2つの事項が考えられる。一つは擋拌時に材料内に 入り，表面に現われないもの．他の一つは表面に現わ れ，石骨注入後模型上に隆起として現われるものであ る. 後者の成因は印象材に混入している気泡が，口腔内 で表面に浮上するのか，あるいは口腔の解剖，生理的状 態によつて生ずるのか判然としない，後者によつて生じ た石旁隆起が㕮合面に生し，知ら間に咬合の狂いを生 じたり，歯頝部，歯間乳頭に発生してクラスプの製作に 困難を感じ，または口蓋㗞壁部に発生してその除去に全 く困難伴う．前者の障碍は值接肉腿でとらえることは できないが，細野氏はその除去の重要なことを述べてい る.表面に現わ机る気泡は歯石除去, 唾液除去で汪とん ど消失するが寒行性は稀で，われわれが日常行い得る範 囲の処置で, 石霄隆起の発生がどのように变化するか実 験を試みたのである。

\section{実験材料及び方法}

\section{処置の方法として}

1）トレーに満したアルギン酸の印象面を，指に水を つけて撫ぜたもの (面処置),

2）印象前に $150 \mathrm{cc}$ の水で被検者にうがいを行わせた もの( 吾い処置),

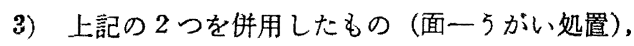

4) 無処置

の 4 群とした。被検者は，全米数を有する口腔状態良好 の者 10 人を党らび，面一ろがい処置，らがい処置，面処 置，無処置の順序で各 2 週間づつ日数をおいて同一術者 で印象を行つた。

\footnotetext{
*日本歯科大学補紷学教室（指道杉崎教授）
}

使用材料は「アルヂックス」を用い，所定の混合比で 1 分間擋拌, 印象採得後固定液江 3 分漫清, 模型用石高 (W/P 50) をパイブレーター上で注入した.

印象材の気泡によつて生じた模型面の石敫粒の測定 は, 金属顕微鏡に Micrometer を取りつけて行い, 1 $\mathrm{mm}$ 以下, $1 \mathrm{~mm} \sim 2 \mathrm{~mm}, 2 \mathrm{~mm}$ 以上の 3 種に分けその 数を求めた。測定部位は最も重要と思われる咬合面, 歯 頝部, 口蓋の 3 つとした。なお口蓋部は，口蓋策譬に起 因して生じたと思われるるののみを数えた.な拀，気泡 発生によつて模型面に現われる小隆起を以下石旁粒と仮 称することとした。

\section{実験成績及び検討}

蒾冠に現われる石管粒は, 大小臼米咬合面, 前蔽舌面 がほとんどで, $2 \mathrm{~mm}$ 以上のものは前蒾舌面に, $1 \mathrm{~mm}$

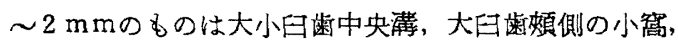
$1 \mathrm{~mm}$ 以下゙のものは小䈪裂溝のあらゆるところに発生す る.

歯䅡部に扰いては, $2 \mathrm{~mm}$ 以上のものは舌側蒾頝部に 多く見られ $1 \mathrm{~mm}$ 以下゙の微細なるのは歯頚縁汇沿つて並 列或は 10 数筒群を作つて括り, 口蓋発生するものは

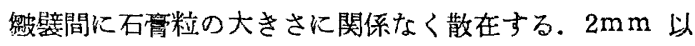
上のものは全て不正型, 1〜2m mのものは楕円型のもの が多く, $1 \mathrm{~mm}$ 以下は肉眼的には球型であつた.

表 1 亿示すよ 5 に（数字は被検者 1 人当りの実数）無 処置で総数 529.6 䇢, この他に未検查の蕆煩移行部等の 数を加へると上下顎に $1,000 \sim 1,500$ 箅の多数の石亮粒 が発生している.

部位的に見ると無処置，面処置群では歯頝部に多く，

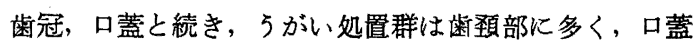
と莼冠部では差があまり見られない，面一らがい処置群 では,やはり蒾䅡部に多いがこれに次いで口蓋, 菊冠部 
表 1 諸処置による石育粒数の変化（平均実数）

\begin{tabular}{|c|c|c|c|c|c|c|c|c|c|c|c|c|c|}
\hline \multicolumn{4}{|c|}{$\begin{array}{cc}\text { 媳查方部位 } \\
\text { 大きさ }\end{array}$} & $\begin{array}{c}\text { 歯 } \\
0 \sim 1\end{array}$ & & $\begin{array}{c}\text { 歯 } \\
0 \sim 1\end{array}$ & \multicolumn{2}{|c|}{ 頚 } & $\begin{array}{c}\text { 口 } \\
0 \sim 1\end{array}$ & \multicolumn{2}{|c|}{ 蓋 } & 総 数 \\
\hline \multirow{2}{*}{ 無 } & \multirow{2}{*}{ 処 } & \multirow{2}{*}{ 置 } & 上 & 100.6 & 2.6 & 0.8 & 207.6 & 5.4 & 0.6 & 45.8 & 4.2 & 0.8 & \multirow{2}{*}{529.6} \\
\hline & & & 下 & 37.8 & 2.2 & 0.2 & 117.6 & 3.2 & 0.2 & & & & \\
\hline \multirow{2}{*}{ 面 } & \multirow{2}{*}{ 処 } & \multirow{2}{*}{ 置 } & 上 & 62.2 & 2.6 & 1.4 & 150.8 & 4.6 & 1.2 & 42.2 & 4.4 & 2.0 & \multirow{2}{*}{367.6} \\
\hline & & & 下 & 20.8 & 1.4 & 0.6 & 72.2 & 0.8 & 0.4 & & & & \\
\hline \multirow{2}{*}{\multicolumn{3}{|c|}{ うがい処 置 }} & 上 & 34.4 & 4.8 & 0.8 & 78.0 & 5.0 & 0.6 & 33.5 & 3.4 & 3.8 & \multirow{2}{*}{289.1} \\
\hline & & & 下 & 29.2 & 3.4 & 0.2 & 87.0 & 4.0 & 1.0 & & & & \\
\hline \multirow{2}{*}{\multicolumn{3}{|c|}{ 面一5がい処置 }} & 上 & 16.6 & 3.4 & 0.4 & 51.6 & 4.2 & 0.8 & 21.0 & 5.6 & 3.6 & \multirow{2}{*}{167.0} \\
\hline & & & 下 & 12.0 & 1.8 & 0.4 & 42.6 & 2.6 & 0.4 & & & & \\
\hline
\end{tabular}

となり処置の方法によりその発生頻度が変化してくる. また, 各処置による石高粒の減少率を見ると蒾冠部が最 む減少し易く次いで蓬䅡部, 口蓋部は最も減少し難い。 以上の事から硬組織より成る蒾冠は減少し易く, 硬組織 と軟組織との接合部でもあり, また, 齿垛等の沈着部で ある蒛䅡部は, 歯冠部程の減少率は求め難く, 軟組織で 複䧴な形態を有する口葢は最も石管粒除去が困難と考え られる.

上顎と下顎では上顎が下顎に比し非常に多く発生して いるが処置の度を增す毎にその差が少くなつてくる．ま えがきに述べたよ 5 に印象材中に入つた気泡が口腔内に 印象を挿入固定している間に浮上するため上顎に多く発 生するとす考えられるが今回の実験のみではこのことに 関しての判断は佾早である.

歯䅡部の石简粒を舌側と煩側に分けて観察すると上 顎, 無処置は煩側97.0, 舌側 116.6 , 面処置は煩側 75.6 舌側81.0,5がい処置は煩側 43.4 舌側 40.2 , 面一5がい処 置は煩側 24.6 舌側 32.0 箅で下顎は無処置, 煩側62.0舌 側 59.0 , 面処直, 頓側 36.0 舌側 37.4 , 万がい処置煩側 53.2 舌側38.8, 面一 5 がい処置煩側25.4舌側20.2箇（画 頝部 1 人当り平均実数) である. 上顎は煩側に比し舌側
が石策粒数多く，下䫈は反対となるがこれは上顎印象時 トレーを後方に押し上げる傾向が強く従つて煩側に圧が 加わり舌側は流机る傾向のためで，また下顎沈反対に下 前方に叔さえるため上顎と反対の結果になると思われ る.このよ5な場合特に上頡では舌側に一列に並んだ, 或は群をなした石管粒が蒾䅡縁から口葢に向つて存在す るから明瞭に判断する事ができる.

処置方法は面一らがい,処置, 万がい,処置, 面処置と 順を追つて石骨粒発生度を減少するが，無処置群と面 処置群は $P\{t \geqq 3.61\}<0.05$, 無処置群之 5 がい，処置 群は $P\{i \geqq 8.94\}<0.01$, 面処置群と 5 がい処置群は $P\{t \geqq 3.17\}<0.05$, 無処置群之面一5 が、処置群は $P\{t \geqq 10.24\}<0.01,5$ がい, 処置群之面一 5 がい, 処置 群は $\mathrm{P}\{\imath \geqq 7.59\}<0.01$, 面処置群と面一らがい処置群 はP $\{\mathrm{t} \geqq 5.4\}<0.05$ とすべての群間に有意の差が見ら れる.

石高粒の大きさと処置による発生率の変化をみると表 2のよ5になる. 各部位に打ける全石蝸粒数を $100 \%$ と してその大きさと発生率の関係を調べた，各部位を通じ て最も発生率の多いのは $1 \mathrm{~mm}$ 以下の小石高粒で各処置 によつて少しづつ減少してくる. また $1 \mathrm{~mm}$ 以上の石亮

表 2 石部粒の大きさと発生率及び処置による変化

\begin{tabular}{|c|c|c|c|c|c|c|c|c|c|}
\hline 処置方法 & $\begin{array}{l}\text { 歯 } \\
0 \sim 1\end{array}$ & $1 \sim 2$ & $\begin{array}{l}\text { 冠 } \\
2 \sim \infty\end{array}$ & $\begin{array}{r}\text { 歯 } \\
0 \sim 1\end{array}$ & $1 \sim 2$ & $\begin{array}{l}\text { 頙 } \\
2 \sim \infty\end{array}$ & $\begin{array}{r}\text { 口 } \\
0 \sim 1\end{array}$ & $1 \sim 2$ & $\begin{array}{l}\text { 䒸 } \\
2 \sim \infty\end{array}$ \\
\hline 処 置 & 96.0 & 3.3 & 0.7 & 97.1 & 2.7 & 0.3 & 90.2 & 8.3 & 1.5 \\
\hline 処置 & 93.3 & 4.5 & 2.2 & 97.0 & 2.4 & 0.7 & 86.8 & 9.1 & 4.1 \\
\hline らがい処置 & 87.4 & 11.3 & 1.3 & 94.0 & 5.1 & 0.9 & 82.2 & 8.4 & 9.4 \\
\hline 面一5がい処置 & 82.7 & 15.0 & 2.3 & 92.2 & 6.7 & 1.2 & 69.5 & 18.5 & 12.9 \\
\hline
\end{tabular}


粒は, 処置の度を強くする程その発生率が高くなるのは 小さい石高粒は除去し易いが，大きなものは除去し難い ことを証明している，面一らがい処置によつて石旁椟の

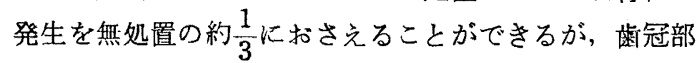
は発生数が割合に少いが藏䅡部では可成り残存する．ま た口蓋部は約 $1 / 2$ の減少程度までで, この部分の石望粒 は不正形の大きなむのが多い.これの除去に際しては, 模型面を傷つけたりして非常に困難なところであつて， 決してこの処置のみで満足できるものではない，以上の 結果から大きな石謷粒と，㐘頝部の石蟹粒を除去する方 法とアルギン酸の気泡の除去に関する実験を続ける予定 である.

$$
\text { ま と め }
$$

1) 石部粒の発生は面一 5 がい処置, 5がい処圆, 面 処置の順に防止されおの打のの処置間にも有意の差があ る.
2）部位的に見ると無処置群，面処置群では歯頝部に 最も多く発生し, 次いで藏冠, 口葢, 5がい処置群では 歯䅡部が多く蒾冠，口蓋は差がなく，面一うがい処置で は歯䫋, 口蓋, 歯冠の順となる.

3) 石管粒の処置による減少率は蒾冠が最も良く減少 し次いで歯頝，口蓋と漸次困難になる.

4) 歯冠, 歯頚部に批いては上顎が下顎に比し発生数 が非常に多いが，処置を加える毎にその差が少くなる.

5 ) 石帝粒発生数は $1 \mathrm{~mm}$ 以下のものが最も多く $1 \mathrm{~m}$ $\mathrm{m} \sim 2 \mathrm{~mm}$ のものがこれに次ぎ, $2 \mathrm{~mm}$ 以上のものは比. 較的少い。

6) 石育粒は各処置によつて $1 \mathrm{~mm}$ 以下のものが最も 減少し易く, $1 \mathrm{~mm}$ 以上のものは減少するがその率が小 さい。

稿を終るに当つて御指導, 御校閲をいただいた杉崎教 授. 並びに御助力を仰いだ清水. 長谷川. 長屋助手に感 謝の意を表す。 